\title{
ДОСЛІДЖЕННЯ РУХУ СЕКЦІЙ РОБОЧИХ ОРГАНІВ ПОСІВНИХ МАШИН 3 МЕТОЮ РЕКУПЕРАЦІЇ ЕНЕРГІЇ
}

\author{
Андрій Войтік ${ }^{1,2}$, к. т. н., Василь Кравченко, ${ }^{1,3}$ к. т. н., \\ Олександр Пушка ${ }^{1,4}$, к. т. н., Тарас Щур ${ }^{5,6}$, к. т. н.

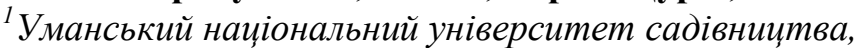 \\ вул. Інститутська 1, м. Умань, Черкаська обл., Украӥна, \\ 2e-mail:av.afex81@gmail.com; ${ }^{3}$ e-mail:kr.vasyl.v@gmail.com ${ }^{4}$ e-mail:pushka79@ukr.net \\ ${ }^{5}$ Львівський національний аграрний університет, \\ вул. Володимира Великого, 1, м. Дубляни, Львівський р-н, Львівська обл., Украӥна, \\ ${ }^{6}$ e-mail: shchurtg@gmail.com
}

https://doi.org/10.31734/agroengineering2021.25.092

\begin{abstract}
Войтік А., Кравченко В., Пушка О., Щур Т. Дослідження руху секцій робочих органів посівних машин 3 метою рекуперації енергії

Рекуперація використаної енергії $є$ одним із напрямів розвитку енергозбереження під час використання машин. Під час роботи сільськогосподарських машин одним із резервів рекуперації енергії $є$ виконання посівних робіт машинами, робочі органи яких розміщені на рухомих секціях, що копіюють поверхню поля. Оскільки поля зазвичай не $\epsilon$ ідеально рівними, тому існує велика ймовірність примусового руху секцій відносно рам машин. Створену таким рухом енергію і можна розглядати як енергію для рекуперації.

Основними схемами кріплення висівних секцій сівалок $є$ паралелограмна та радіальна. Виконавчим механізмом системи рекуперації руху секцій сівалок буде гідроциліндр, рух поршня якого створюватиме потік робочої рідини. У паралелограмній підвісці розмістимо гідроциліндр по лінії більшої діагоналі паралелограма. У радіальній підвісці сошникової секції хід штока гідроциліндра буде залежати від зміни вертикального положення сошника, а також від конструктивних особливостей секції.

Результати розрахунків показують, що за однакових зовнішніх умов, а саме нерівностей поля, і за фактичних розмірів паралелограмної та радіальної підвісок робочих органів вибраних сівалок зміна довжини проєктованого штока гідроциліндра радіальної підвіски менш виражена, ніж паралелограмної підвіски. Також проведені теоретичні дослідження з визначення можливих переміщень штока, вмонтованого в багатошарнірні секції посівних машин, показали, що за використання гідроциліндра 3 діаметром поршня 40 мм вони дозволяють створювати подачу робочої рідини до 8,1 л/хв для паралелограмних секцій сівалки та до 3,9 л/хв для радіальних підвісок секцій. Ключові слова: рекуперація енергії, гідравлічний циліндр, секції робочих органів, посівні машини.
\end{abstract}

Voitik A., Kravchenko V., Pushka O., Shchur T. Investigation of movement of the sections of seeding machine working bodies for the purpose of energy recovery

Recovery of used energy is one of the directions of energy saving development while using machines and mechanisms. This uses the potential energy accumulated by massive mechanisms or the kinetic energy of the moving elements of machines.

There are also energy recovery reserves in the operation of agricultural machinery. One of such processes is the performance of sowing work by machines, the working bodies of which are placed on moving sections that copy the surface of the field. Since the fields are usually not perfectly flat, there is a high probability of forced movement of the sections relative to the machine frames. The energy generated by the movement of the sections can be considered as energy that can be used for recovery.

Today, the most popular schemes of fastening of sowing sections of drills are parallelogram and radial. The actuator of the recovery system of the movement of the drills sections will be a hydraulic cylinder, the movement of the piston which will create a flow of working fluid. In the parallelogram suspension, the hydraulic cylinder is placed along the line of the larger diagonal of the parallelogram. Accordingly, when copying the relief of the field, the position of the links of the parallelogram mechanism will change, which will cause changes in the length of the diagonal, and in our case - is the movement of the hydraulic cylinder rod. In the radial suspension of the opener section, the stroke of the hydraulic cylinder 
rod will depend on the change of the vertical position of the opener, as well as on the design features of the section: cross section of the central frame of the opener sections, height of the opener relative to the frame.

As a result of calculations, the equation for definition of length of a course of the hydraulic cylinder rod is received. According to the obtained equations, it is determined that with the field irregularities of $2 \mathrm{~cm}$, the change in the length of the hydraulic cylinder rod for the radial suspension will be within $\Delta n=0.3 \mathrm{~cm}$, and for the parallelogram suspension $\Delta p=0.8 \mathrm{~cm}$. The flow of the working fluid will vary: for the parallelogram suspension sections $4.2-8.21 / \mathrm{min}$, for the radial suspension $1.9-3.9 \mathrm{l} / \mathrm{min}$ at the speed of the unit $2-4 \mathrm{~m} / \mathrm{s}$ and provided the use of a hydraulic cylinder with a piston diameter of $40 \mathrm{~mm}$.

The obtained data show that the recovery energy from the movement of sections of the working bodies when copying the terrain deserves attention and requires further research, which must substantiate the hydraulic scheme of the device and methods of energy storage.

Key words: energy recovery, hydraulic cylinder, working body sections, seeding machines.

Постановка проблеми. Однією 3 найголовніших проблем, над якими сьогодні працюють вчені, є енергозбереження в усіх сферах діяльності людини. Особливо це стосується галузей, які є найенергонасиченішими. До таких галузей можна віднести й сільське господарство, де польові роботи виконуються 3 використанням потужних двигунів внутрішнього згоряння.

Одним із напрямів розвитку енергозбереження за використання машин i механізмів $\epsilon$ рекуперація використаної енергії 3 метою повторного їі використання. При цьому використовується потенціальна енергія, накопичена масивними механізмами, або кінетична енергія рухомих елементів машин. Найпоширенішим способом накопичення енергії $\epsilon$ використання гідроакумуляторів, але 3 цією метою також використовують додаткові мехатронні системи, які дозволяють перетворювати механічну енергію на електричну.

Під час роботи сільськогосподарських машин також є резерви рекуперації енергії. Одним із таких процесів є виконання грунтообробних або посівних робіт машинами, робочі органи яких розміщені на рухомих секціях, що копіюють поверхню поля. Оскільки поля зазвичай не є ідеально рівними, існує велика ймовірність примусового руху секцій відносно рам машин. Вони долають при цьому опір різних притискних механізмів, найчастіше витих пружин, витрачаючи на це значну частину енергії. Саме цю кінетичну енергію, створену підняттям та опусканням секцій, і можна розглядати як потенційну енергію для рекуперації.

Аналіз останніх досліджень і публікацій. Збирання й накопичення енергії, яка генерується внаслідок виконання основних процесів роботи, поширене в багатьох галузях [3; 11]. Здорожчання палива та перехід до більш жорстких стандартів щодо шкідливих викидів двигунів внутрішнього згоряння є каталізатором до збільшення кількості робіт, спрямованих на дослідження рекуперації використаної енергіï [4]. Значною мірою це сто- сується навантажувально-розвантажувальних машин, таких як екскаватори й телескопічні навантажувачі, де потенціальна енергія піднятих вантажів і важких підіймальних механізмів може регенеруватись і накопичуватися під час їх опускання [8].

Але, для прикладу, у роботі [9] пропонується принцип збирання енергії від автомобілів, які проїжджають через автомобільний тунель, для обслуговування цього тунелю. Запропонована система складається 3 чотирьох основних елементів: «лежачого поліцейського» 3 рухомою підвіскою, генератора i модулів накопичення енергії. Проїжджаючи через цього «лежачого поліцейського», автомобілі тиснуть на нього i переміщують донизу, генеруючи таким чином енергію та приводячи в дію генератор, а підвіска поліцейського повертає його в попереднє положення.

У залізничному транспорті пропонуються засоби рекуперації енергії [5] від проїжджаючих потягів за допомогою збирання енергії вібрації колій. Згенерована енергія збирається в накопичувачах та використовується для обслуговування цих шляхопроводів.

Також поширеним способом рекуперації енергії на транспортних засобах $є$ використання енергії гальмування. В основному така технологія забезпечує перетворення кінетичної енергії на електричну, яка потім може зберігатися в спеціальних накопичувачах, таких як акумулятор або ультраконденсатор, для повторного використання під час руху [7]. У сільськогосподарських машинах така концепція розглядається в роботі [10], фірмою ZF було встановлено електропривод на колісну вісь причепа Fliegl: на середню вісь причепа було поставлено два високооборотні трифазні асинхронні двигуни 3 редуктором, які працюють від напруги $400 \mathrm{~B}$, ці електромотори було інтегровано в маточини коліс. Така гібридна система ZF дозволяє рекуперувати енергію під час руху згори.

Питання рекуперації енергії в сільськогосподарських машинах розглянуто в роботі [2]. Тут 
для зменшення впливу змінного навантаження на режими роботи агрегату запропоновано обладнати трансмісію трактора механічним накопичувачем енергіï. За рахунок властивостей маховика накопичувач може миттєво сприймати й повертати накопичену енергію в період пікових навантажень.

Багато досліджень спрямовано на розгляд отримання енергії від нерівностей доріг через підвіску транспортних засобів [15]. Зокрема, у роботі [12] досліджено модель гідропневматичної регенеративної системи підвіски порівняно зі звичайною підвіскою. За рахунок коливань у системі підвіски гідравлічний циліндр прокачує рідину через гідравлічний мотор, який, своєю чергою, з'єднаний із генератором струму. Отримана електрична енергія накопичується в акумуляторній батареї.

Автори роботи [13] представили розробку гідроелектричної регенеративної підвіски автомобілів. Дослідження показали, що зі збільшенням швидкості руху автомобіля від 10 до $30 \mathrm{~m} / \mathrm{c}$ кількість отриманої енергії зростає від 5 до 160 Вт залежно від класу доріг.

Також дослідження гідроелектричної регенеративної підвіски показало, що за будь-якої частоти коливання потужність регенеративної енергії спочатку зростає, а потім зі збільшенням опору зменшується [6], а частота коливань колеса автомобіля дуже добре забезпечує генерацію відновлюваної енергії.

Рух підвіски автомобілів є найбільш близьким до руху секцій сільськогосподарських машин. Положення секцій одноланкових та багатоланкових навісних систем робочих органів культиваторів, а саме кутове переміщення у вертикальній площині, залежно від конструктивних параметрів секції та сил, прикладених до неї, знайдено авторами [1]. У цій праці вказано, що інтенсивність зміни кута відхилення секції у вертикальній площині за багатоланкового приєднання менша, ніж за одноланкового. Також у роботі [14] зроблено висновки, що на коливання ланок паралелограмного механізму підвісу секцій найбільше впливають вага секції робочих органів, сила опору грунту, кут встановлення ланок секцій та сила тиску притискних пружин.

Таким чином, у розглянутих джерелах комплексного дослідження щодо можливості рекуперації енергії сільськогосподарськими машинами, і саме машинами, які мають секційне кріплення робочих органів 3 можливістю копіювання поверхні поля, не відображено.

Постановка завдання. Наше завдання дослідити рух багатоланкових шарнірних секцій посівних машин із метою визначення переміщення штока вмонтованого в них притискного гідроциліндра залежно від швидкості руху агрегату та рельєфу поля.

Виклад основного матеріалу. Розглянемо найпопулярніші на ринку схеми кріплення висівних (сошникових) секцій сівалок (рис. 1).

Паралелограмний механізм кріплення сошникових секцій (див. рис. 1, а) досить часто зустрічається в конструкціях сівалок, особливо сівалок точного висіву. Він дає змогу копіювати рельєф поля та забезпечувати достатнє притискне зусилля секції до грунту. Сам механізм являє собою шарнірний чотириланковий вузол у формі паралелограма, який короткими сторонами кріпиться $з$ одного боку до центральної рами сівалки, а з другого - до рами секції. У середині паралелограмного механізму може розміщуватися пружинний або гідравлічний вузол для регулювання жорсткості системи, а також притискного зусилля.

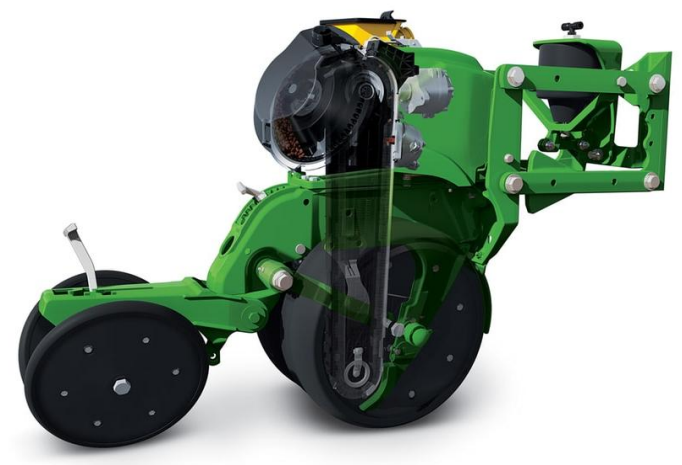

$a$

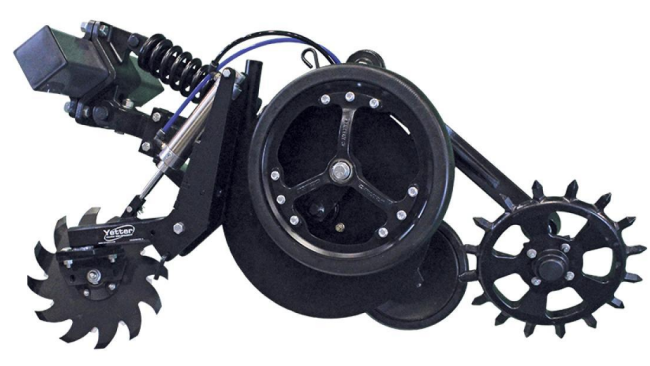

6

Рис. 1. Типи підвісок сошникових секцій: $a$ ) паралелограмна (Jonh Deere); б) радіальна 3 пружинним довантаженням (Yetter)

Fig. 1. Types of suspensions of opener sections: $a$ ) parallelogram (Jonh Deere); б) radial with spring loading (Yetter) 
Радіальна підвіска (див. рис. 1, б) $є$ простішою за конструкцією та має меншу вагу. Однак копіювання рельєфу та притискне зусилля на сошнику тут менше. Тому сучасні виробники сівалок додають до конструкції підвіски пружинний або гідравлічний механізм, що створює додатковий тиск на сошник, покращуючи таким чином дотримання заданої глибини висіву та проникнення сошника в грунт. У результаті маємо наступну конструкцію. До центральної рами сівалки в нижній частині шарнірно кріпиться підвіска, яка являє собою лише одну ланку. 3 іншого боку до ланки також шарнірно кріпиться сама сошникова секція. Зверху до центральної рами кріпиться механізм регулювання притискного зусилля, який іншим кінцем приєднаний до сошникової секції вище кріплення ланки підвіски. Таким чином утворюється шарнірний чотирикутник, який, як правило, може набувати довільної форми.

Під час руху агрегатів по полю, секції, долаючи опір притискних механізмів, здійснюють вертикальний рух відносно рами машини. 3 метою рекуперації енергії в результаті вертикальних переміщень сошників при копіюванні рельєфу поля додамо до конструкції секцій гідроциліндри, які відповідатимуть за притискне зусилля та одночасно прокачуватимуть робочу рідину в разі зміни положення секції.

Проведемо дослідження руху розглянутих вище секцій робочих органів 3 метою визначення їхніх можливих переміщень. Зобразимо схематично конструкції підвісок секцій сошників (рис. 2).

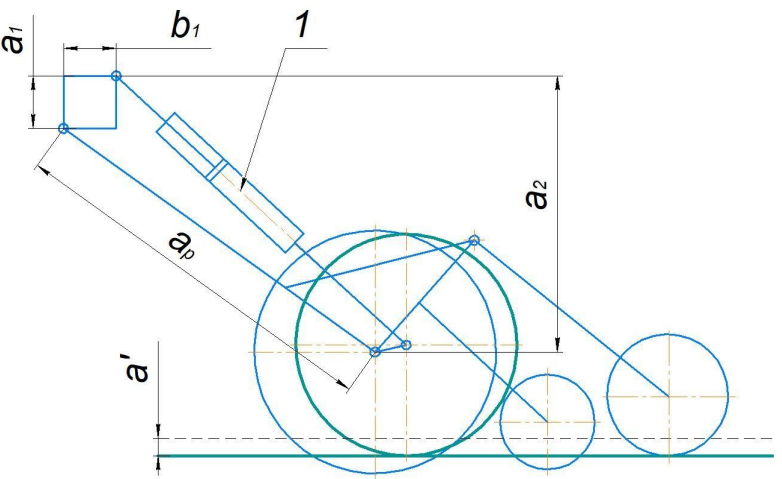

$\sigma$

Рис. 2. Схеми підвісок сошникових секцій: $a$ ) паралелограмна; б) радіальна

Fig. 2. Schemes of suspension brackets of opener sections: $a$ ) parallelogram; б) radial

У паралелограмній підвісці (див. рис. 2, а) розмістимо гідроциліндр (1) по лінії більшої діагоналі паралелограма. Відповідно під час копіювання рельєфу поля положення ланок паралелограмного механізму змінюватиметься, що спричинюватиме зміни довжини діагоналі, а в нашому випадку - це рух штока гідроциліндра. Цей рух, тобто хід штока, визначатимемо як різницю двох довжин діагоналі паралелограма в найнижчому та найвищому положенні секції сівалки. Ця величина залежатиме від: довжини короткої ланки паралелограма $a$; довжини довгої ланки паралелограма $b$; кута положення паралелограмного механізму відносно горизонту $\alpha$; висоти переміщення сошника у вертикальній площині від найнижчого до найвищого положення $a^{\prime}$.

У випадку радіальної підвіски сошникової секції (див. рис. 2, б) хід штока гідроциліндра 1 в разі зміни вертикального положення сошника на величину $a$ ' залежатиме також від конструктивних особливостей секції. Для розв'язання геометричної задачі нам потрібні такі розміри: поперечний переріз центральної рами сошникових секцій, що визначається розмірами $a_{1}$ та $b_{1}$; висота розміщення сошника відносно рами $a_{2}$; довжина ланки радіальної підвіски $a_{p}$.

Введемо змінну $v$, яка визначатиме положення сошника відносно балки центральної рами, враховуючи конструктивні параметри секції та початкове положення сошника. Значення цієї змінної знайдено із застосуванням методів класичної геометрії для кожного типу підвіски сошникової секції. Враховуючи цю змінну, отримаємо такі рівняння для визначення довжини ходу штока гідроциліндра:

- для паралелограмної підвіски:

$$
\Delta l_{n}(\vartheta)=\sqrt{a^{2}+b^{2}+2 a b \cdot \cos (0,5 \pi-\arcsin (\vartheta))},
$$


де $\Delta l_{n}$ - довжина ходу штока гідроциліндра паралелограмної підвіски секцій, м; $\vartheta-$ змінна, яка визначає положення робочих органів відносно балки центральної рами; $a$ - довжина короткої ланки паралелограма, м; $b$ - довжина довгої ланки паралелограма, м;

- для радіальної підвіски:

$$
\Delta l_{p}(\vartheta)=\sqrt{\vartheta^{2}+\left(\sqrt{a_{p}^{2}-\left(\vartheta-a_{1}\right)^{2}}-b_{1}\right)^{2}},
$$

де $\Delta l_{p}$ - довжина ходу штока гідроциліндра радіальної підвіски секцій, м; $a_{p}$ - довжина ланки радіальної підвіски, м; $a_{1}, b_{1}-$ поперечний переріз центральної балки секцій робочих органів, м.

Визначають величину ходу штока гідроциліндра в обох випадках як різницю між найбільшим i найменшим значенням довжини ланки 1 (див. рис. 2), яка змінюється в результаті вертикальних переміщень сошника під час копіювання рельєфу поверхні поля.

Рельєф поля опишемо як гармонічні коливання секції сівалки 3 певною амплітудою (відповідає за величину зміни вертикальної складової положення секції) та частотою, яка фактично залежить від довжини хвилі гармонічних коливань та швидкості руху сівалки в поздовжньому напрямку (фактично робоча швидкість сівалки).

Для візуалізації отриманих даних використаємо отримані в MatLab залежності та проаналізуємо зміну довжини штока гідроциліндра від висоти розміщення сошника відносно початкового положення для сошникових секцій сівалок з паралелограмною та радіальною підвіскою (рис. 3).
Отримані в результаті розрахунків за формулами (1) та (2) графіки показують, що за однакових зовнішніх умов, а саме нерівностей поля, та за фактичних розмірів паралелограмної і радіальної підвісок робочих органів вибраних сівалок зміна довжини проєктованого штока гідроциліндра радіальної підвіски менш виражена, ніж паралелограмної. Так, зміна нерівностей поля від початкового положення $(0 \mathrm{~cm})$ на $2 \mathrm{~cm}$ призводить до зміни довжини штока гідроциліндра в межах $\Delta_{\mathrm{I}}=0,504-0,501=0,003$ м для радіальної підвіски та $\Delta_{\mathrm{p}}=0,490-0,482=0,008$ м для паралелограмної підвіски, тобто тут існує різниця майже в три рази.

Визначивши можливі переміщення штока гідроциліндра, можливо дослідити створюваний таким гідроциліндром потік робочої рідини. Для побудови графіка залежності подачі робочої рідини від швидкості руху сівалки використаємо гідроциліндр із діаметром поршня 40 мм.

У цьому разі гідроциліндр працюватиме як поршневий насос, який під час переміщення поршня створює потік робочої рідини. Параметри цього потоку будуть залежати від робочого об'єму гідроциліндра та частоти його коливань:

$$
Q(t)=S \cdot h(t),
$$

де $Q(t)$ - подача робочої рідини гідроциліндром, $\mathrm{m}^{3} / \mathrm{c} ; S$ - площа поршня, $\mathrm{m}^{2} ; h(t)$ - швидкість поршня, м/c.

\section{Хід штока гідроциліндра залежно від зміни висоти розміщення секції сівалки}

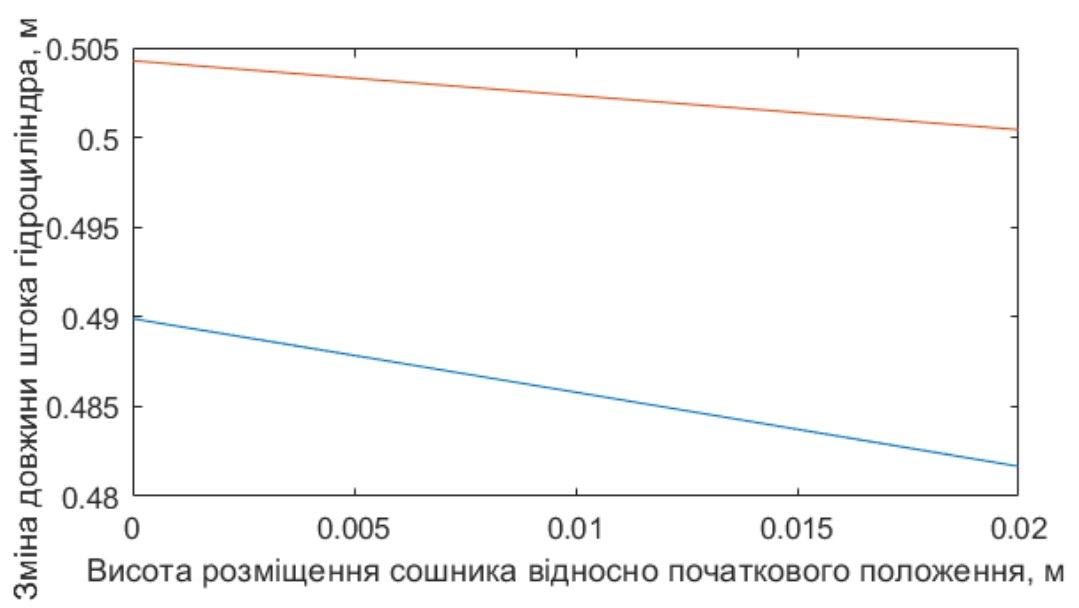

$$
\begin{aligned}
& \text { паралелограмна підвіска } \\
& \text { радіальна підвіска }
\end{aligned}
$$

Рис. 3. Хід штока гідроциліндра залежно від зміни висоти розміщення секцій сівалок

Fig. 3. The stroke of the hydraulic cylinder rod depending on the change in the height of the seeder sections 


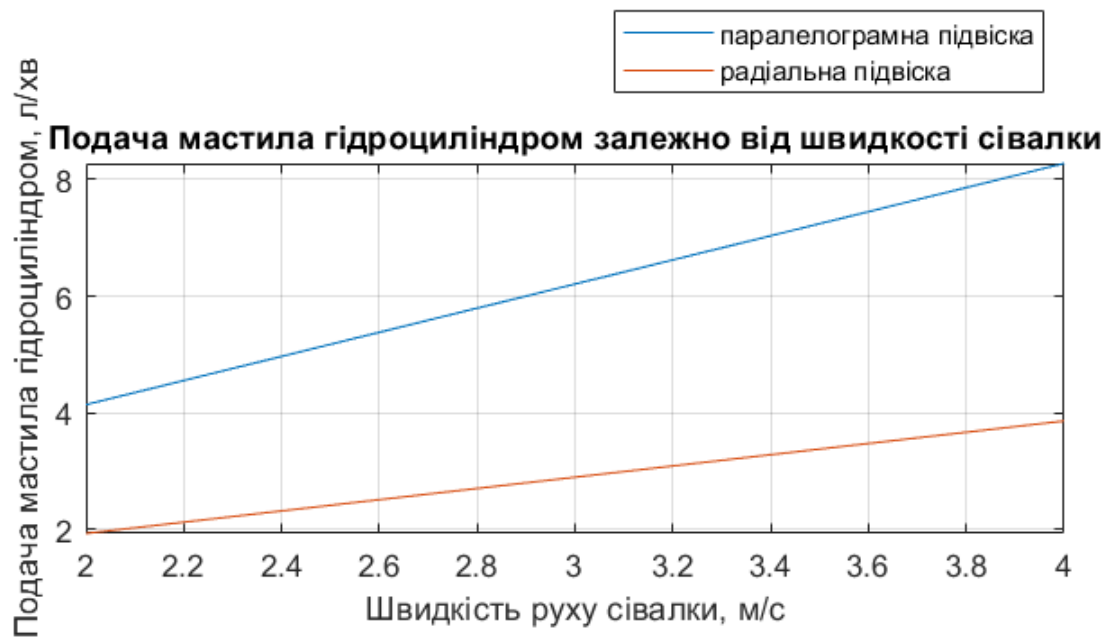

Рис. 4. Теоретична подача робочої рідини залежно від швидкості руху агрегату Fig. 4. Theoretical supply of working fluid depending on the machine speed

Отримана залежність (див. рис. 4) демонструє, що в межах прийнятих нерівностей поля та розрахованого відповідно до них руху штока гідроциліндра подача робочої рідини збільшується зі збільшенням швидкості агрегату прямолінійно. Оскільки хід штока в паралелограмній і радіальній підвісках відрізняється (див. рис. 3), то ця різниця також простежується і в подачі робочої рідини цими секціями сівалок. $\mathrm{y}$ паралелограмній підвісці подача у вибраних межах зміни швидкості руху агрегату зростає від 4,2 до 8,2 л/хв, тоді як у радіальній підвісці секції за таких самих параметрів швидкості подача зростатиме з 1,9 до 3,9 л/хв, тобто буде меншою майже удвічі. Також слід зауважити, що в обох випадках збільшення швидкості руху у два рази призводить i до збільшення подачі робочої рідини штоком гідроциліндра майже у два рази.

Висновки. Таким чином, проведені теоретичні дослідження 3 визначення можливих переміщень штока, вмонтованого в багатошарнірні секції посівних машин, показали, що за використання гідроциліндра 3 діаметром поршня 40 мм вони дають змогу створювати подачу робочої рідини до 8,1 л/хв для паралелограмних секцій сівалки та до 3,9 л/хв для радіальних підвісок секцій. Отримані дані показують, що дослідження, спрямовані на отримання рекупераційної енергії від руху секцій робочих органів під час копіювання рельєфу поля, заслуговують на увагу й потребують продовження. У подальших дослідженнях необхідно обгрунтувати гідравлічну схему роботи пристрою та способи накопичення енергії.

\section{Бібліографічний список}

1. Василенко П. М., Бабий П. Т. Культиваторы (конструкция, теория и расчет). Киев, 1961.239 с.

2. Олядничук Р. В. Применение накопителя энергии в составе почвообрабатывающего агрегата. MOTROL Commission of Motorization and Energetics in Agriculture. 2015. Vol. 17, No. 3. P. 264-269.

3. Семенов О., Підлісний В., Слива О., Якубов I. Регенерація теплової енергії в процесах стерилізації і пастеризації. Вісник Львівського національного аграрного університету: агроінженерні дослідження. 2016. № 20. C. 198-202.

4. A hydraulic test stand for demonstrating the operation of Eaton's energy recovery system (ERS) / M. Wang et al. 10th International Fluid Power Conference, March 8-10, 2016. Dresden, 2016. Vol. 1. P. 219-230.

5. A portable high-efficiency electromagnetic energy harvesting system using supercapacitors for renewable energy applications in railroads / X. Zhang et al. Energy Conversion and Management. 2016. Vol. 118. P. 287-294. doi: 10.1016/j.enconman.2016.04.012.

6. An Optimal Algorithm for Energy Recovery of Hydraulic Electromagnetic Energy-Regenerative Shock Absorber / Z. Fang et al. Applied Mathematics \& Information Sciences. 2013. Sci. 7, No. 6. P. 2207-2214. doi: 10.12785/amis/070610.

7. Co-operative control for regenerative braking and friction braking to increase energy recovery without wheel lock / J. W. Ko et al. International Journal of Automotive Technology. 2014. 15(2). P. 253-262. doi: 10.1007/s12239014-0026-6.

8. Comparison of energy saving and recovery systems for hydraulic mobile machines / A. Bonavolonta et 
al. AIP Conference Proceedings. 2019. 2191. doi: $10.1063 / 1.5138758$.

9. Design, modelling and practical tests on a highvoltage kinetic energy harvesting (EH) system for a renewable road tunnel based on linear alternators / Z. Zhang et al. Applied Energy. 2016. Vol. 164. P. 152-161. doi: 10.1016/j.apenergy.2015.11.096.

10. Götz M., Gumpoltsberger G., Weinman O. Electrification and Driver Assist Technology in the ZF Innovation Tractor. ATZheavy duty worldwide. 2016. 9. P. 16-21. doi: 10.1007/s41321-016-0539-1.

11. Paulsen K., Hensel F. Introduction of a new Energy Recovery System - optimized for the combination with renewable energy. Conference on Desalination and the Environment. Santa Margherita, Italy, 22-26 May. Santa Margherita, 2005. Vol. 184, issues 1-3. P. 211-215. doi: 10.1016/j.desal.2005.03.060.
12. Performance Evaluation and Damping Characteristics of Hydro-Pneumatic Regenerative Suspension System / M. Awad et al. International Journal of Applied Engineering Research. 2018. 13(7). P. 5436-5442.

13. The ride comfort and energy-regenerative characteristics analysis of hydraulic-electricity energy regenerative suspension / B. Gong et al. Journal of Vibroengineering. 2016. Vol. 18, issue 3. P. 1765-1782. doi: 10.21595/jve.2016.16746.

14. The stability stroke of cotton seeder moulder / F. Mamatov et al. IOP Conference Series: Materials Science and Engineering. 2020. 883. doi: 10.1088/1757899X/883/1/012145.

15. Zheng P., Gao J. Damping force and energy recovery analysis of regenerative hydraulic electric suspension system under road excitation: modelling and numerical simulation. Mathematical Biosciences and Engineering. 2019. 16(6). P. 6298-6318. doi: $10.3934 / \mathrm{mbe} .2019314$

Стаття надійшла 22.08.2021 